Sri Lanka J. Aquat. Sci. 20 (2) (2015): 39-47

\title{
Fish offal based aqua-feed for rearing post-larvae of freshwater prawn, Macrobrachium rosenbergii
}

\author{
M.H.S. Ariyaratne ${ }^{1}$ and Ruchira Amaraweera ${ }^{2}$ \\ ${ }^{1}$ National Aquatic Resources Research and Development Agency, Crow \\ Island, Colombo15, Sri Lanka; ${ }^{2}$ Regional Research Centre, National Aquatic \\ Resources Research and Development Agency, Rekawa, Tangalle, Sri Lanka
}

Corresponding Author: somaariyaratne@gmail.com

\begin{abstract}
Market demand for freshwater prawn (Macrobrachium rosenbergii) is high in Sri Lanka. The national agencies stock 20 days old post-larvae $\left(\mathrm{PL}_{20}\right)$ of this prawns in minor perennial reservoirs but the yield is low due to high mortality. There is a need to develop a low-cost nursing strategy for $\mathrm{PL}_{20}$ before stocking. This research was conducted to evaluate the potential for nursing $\mathrm{PL}_{20}$ in backyard nurseries using lowcost fish offal-based aqua-feed. The trial was carried out in a backyard nursery comprising 6 cement tanks $\left(1.73 \mathrm{~m}^{3)}\right.$ each.

One hundred $\mathrm{PL}_{20}$ were stocked in each tank (stocking density=57 $\mathrm{PL}_{20} \mathrm{~m}^{-2}$ ). There were two feeding treatments each with three replicates: (1) fish offal-based aqua feed (Af), and (2) commercial prawn feed (Cf) at a rate of 5\% of body weight. Af was made using a 1:1 mixture of rice bran and boiled fish-offal and $\mathrm{Cf}$ was purchased from the market. The feeding rate was adjusted for body weight using biweekly sampling and the trial was conducted for 96 days.

Average Daily Growth (ADG) of PL 20 fed with Af on days 16, 30 and 47 were higher than the ADG of $\mathrm{PL}_{20}$ fed with $\mathrm{Cf}$ on same days but not significantly different ( $p>0.05)$. However, ADG of $\mathrm{PL}_{20}$ that fed on Af on day 85 and 96 were lower than that were fed on $\mathrm{Cf}$ on same days but not significantly different $(\mathrm{p}>0.05)$. Nevertheless, ADG of the PL 20 that fed on Af on day $63\left(0.0038 \pm 0.0001 \mathrm{~g} \mathrm{day}^{-1}\right)$ was significantly lower $(\mathrm{p}<0.05)$ than the ADG of $\mathrm{PL}_{20}$ that fed on $\mathrm{Cf}$ on same day $\left(0.0072 \pm 0.0012 \mathrm{~g} \mathrm{day}^{-1}\right)$. Specific Growth Rate (SGR) in days 16, 30, 47, 85 and 96 of $\mathrm{PL}_{20}$ fed with Af were not significantly different from SGR of PL 20 fed with $\mathrm{Cf}$ in same days. Nevertheless, SGR in day 63 in Af (5.9382 \pm 0.0523$)$ and $\mathrm{Cf}$ $(6.2961 \pm 0.0771)$ were significantly different $(\mathrm{p}<0.05)$. Weight Gain $(\mathrm{WG})$ of $\mathrm{PL}_{20}$ that fed on $\mathrm{Cf}$ on days 16, 30, 47 and 96 were not significantly different $(\mathrm{P}>0.05)$ from WG of $\mathrm{PL}_{20}$ that fed on Af on same days. However, WG of the $\mathrm{PL}_{20}$ that fed on Cf on days 63 and $85(0.4551 \pm 0.0784$ and $1.0117 \pm 0.0944 \mathrm{~g}$ respectively) were significantly different $(\mathrm{p}<0.05)$ from $\mathrm{WG}$ of $\mathrm{PL}_{20}$ that fed on Af on same days $(0.2374$ \pm 0.006 and $0.7508 \pm 0.0276 \mathrm{~g}$ ). Percentage survival rates on days $16,30,47$ and 63 of $\mathrm{PL}_{20}$ fed with Af were higher than those of $\mathrm{PL}_{20}$ fed with $\mathrm{Cf}$ on same days but not
\end{abstract}


significantly different ( $p>0.05)$ except the values on day 63 in Af $(56.67 \pm 1.15)$ and in $\mathrm{Cf}(50.3 \pm 1.0)$. However, \% survival of $\mathrm{PL}_{20}$ that were fed with Af on days 85 and 96 were lower than that of the $\mathrm{PL}_{20}$ that fed on $\mathrm{Cf}$ but not significantly different $(\mathrm{p}>0.05)$.

Fish offal-based aqua-feed can therefore be effectively used for nursing $\mathrm{PL}_{20}$ of $M$. rosenbergii for 47 days in backyard nurseries.

Keywords: Macrobrachium rosenbergii, fish offal, aqua-feed, low level protein diet

\section{Introduction}

Giant Freshwater Prawn, Macrobrachium rosenbergii is a main candidate for aquaculture in inland waters due to the attributes of becoming gravid in captivity, availability of established techniques for seed production in hatcheries and grow-out culture. Also, there are no major disease problems and has wide consumer acceptance and a high market value. This species has recently emerged as an important shellfish species for culture in south Asian countries after the significant losses observed in penaeid shrimp culture during mid-1990s due to viral diseases (Hasanuzzaman et al. 2009).

Freshwater prawn is an omnivore (Balazs and Ross 1976) and can be grown using low cost aqua-feed (Mitra et al. 2005). Freshwater Prawn grows well even with $15 \%$ protein feeds in ponds with sufficient natural food. Trials of Freshwater Prawn culture have been conducted in Sri Lanka by Hettiarachchi and Kularatne (1988).They indicated that the low survival rates in their trials were due to the stocking of $\mathrm{PL}_{20}$ stage and suggested that stocking of older PL is necessary to improve the survival rates. National Aquaculture Development Authority (NAQDA) also has stocked $M$. rosenbergii larvae of $\mathrm{PL}_{20}$ stage in 9 minor perennial reservoirs and has obtained poor survival (J.M. Asoka, Pers. Comm. 2007).To improve the survival and production in Macrobrachium culture it appears that there is a necessity to rear Macrobrachium larvae of $\mathrm{PL}_{20}$ for a further period of more than 20 days in backyard nurseries before stocking in aquaculture systems. In the present study, an attempt was made to rear the Macrobrachium larvae in nursery systems for a period of 96 days using a low cost feed prepared incorporating fish offal.

\section{Materials and Methods}

The trial was carried out in the Regional Research Centre of National Aquatic Resources Research and Development Agency (NARA) in Rekawa, Tangalle in Hambantota district. PL 20 of $M$. rosenbergii were obtained from Freshwater Prawn Hatchery in Pambala, North-Central province in Sri Lanka. One hundred PL 20 were stocked in backyard nursery comprising 6 cement tanks $\left(1.73 \mathrm{~m}^{3}\right)$. The stocking density used was $57 \mathrm{PL}_{20} \mathrm{~m}^{-2}$.

There were two feed treatments with three replicates: In treatment (1) prawns were fed with fish-offal based aqua-feed (Af), and in treatment (2) with commercial 
prawn feed (Cf). In both treatments prawn larvae were fed at a rate of $5 \%$ of body weight. Total ration was divided into two parts; about $1 / 3$ of the total feed was given at $10^{\text {th }} \mathrm{hr}$ and the remaining amount at $19^{\text {th }} \mathrm{hr}$. Af was made using a 1:1 mixture of rice bran and boiled fish offal and Cf was purchased from Gold Coin Feed Mills (Lanka) Ltd, Colombo, Sri Lanka. The feeding rate was adjusted for body weight using bi-weekly sampling and the trial was conducted for 96 days.

The proximate compositions of Af and $\mathrm{Cf}$ were determined according to the standard methods given in APHA (1985). Percentage moisture content was determined by oven drying weighed samples in porcelain crucibles at $105^{\circ} \mathrm{C}$ for 24 hours. The total volatile matter lost at this temperature was taken as the moisture content. Percentage ash content was determined by incinerating the dried samples overnight in a Muffle furnace at $550^{\circ} \mathrm{C}$. Percentage protein $(\mathrm{N} \times 6.25)$ was estimated by semi-micro Kjeldahl digestion, distillation and titration. Percentage fat content was determined through chloroform method (Bligh and Dyer 1959).

Sampling was carried out in each tank on the days 16, 30, 47, 63, 85 and 96.Randomly selected 20 juveniles were taken as a sample from each tank in each occasion. The initial and subsequent weekly weight gains (g) were recorded on a sensitive top loading balance (Precisa $120 \mathrm{~A}$ ).

The growth performances of the Macrobraccium larvae that were fed on 2 different diets were assessed using Specific growth rate (SGR), Average Daily Growth (ADG), Condition Factor (K), Weight Gain (WG) and \% Survival. These were calculated using standard definitions from Ricker (1979) and Fasakin et al. (2001).

Means and standard deviations were calculated and expressed as mean \pm SD. Student's t-test (Graph PadPrism Software www.graphpad.com) was employed to compare the growth performance of post-larvae that fed on Af and Cf.

\section{Results}

The Average Daily Growth (ADG) and Specific Growth Rate (SGR) of the Freshwater prawn that fed on fish-offal based aqua-feed (Af) and commercial feed (Cf) within the 96 days of rearing period are shown in Fig. 1. The ADG of the larvae fed on Af and Cf were not significantly different in the day 16, 30, 47, 85 and 96 but significantly different in day 63 respectively. The SGR of the larvae fed on Af and Cf were not significantly different in the day16, 30, 47, 85 and 96 but significantly different in day 63 only. After the day 47, the ADG of the PL fed on Af has shown a slight increase, which was recorded as $0.0038 \pm 0.0003$ and on the day 63 ADG was $0.0038 \pm 0.0001 \mathrm{~g} \mathrm{day}^{-1}$. After day 63, it has increased but lower than the ADG of the PL fed on Cf. 

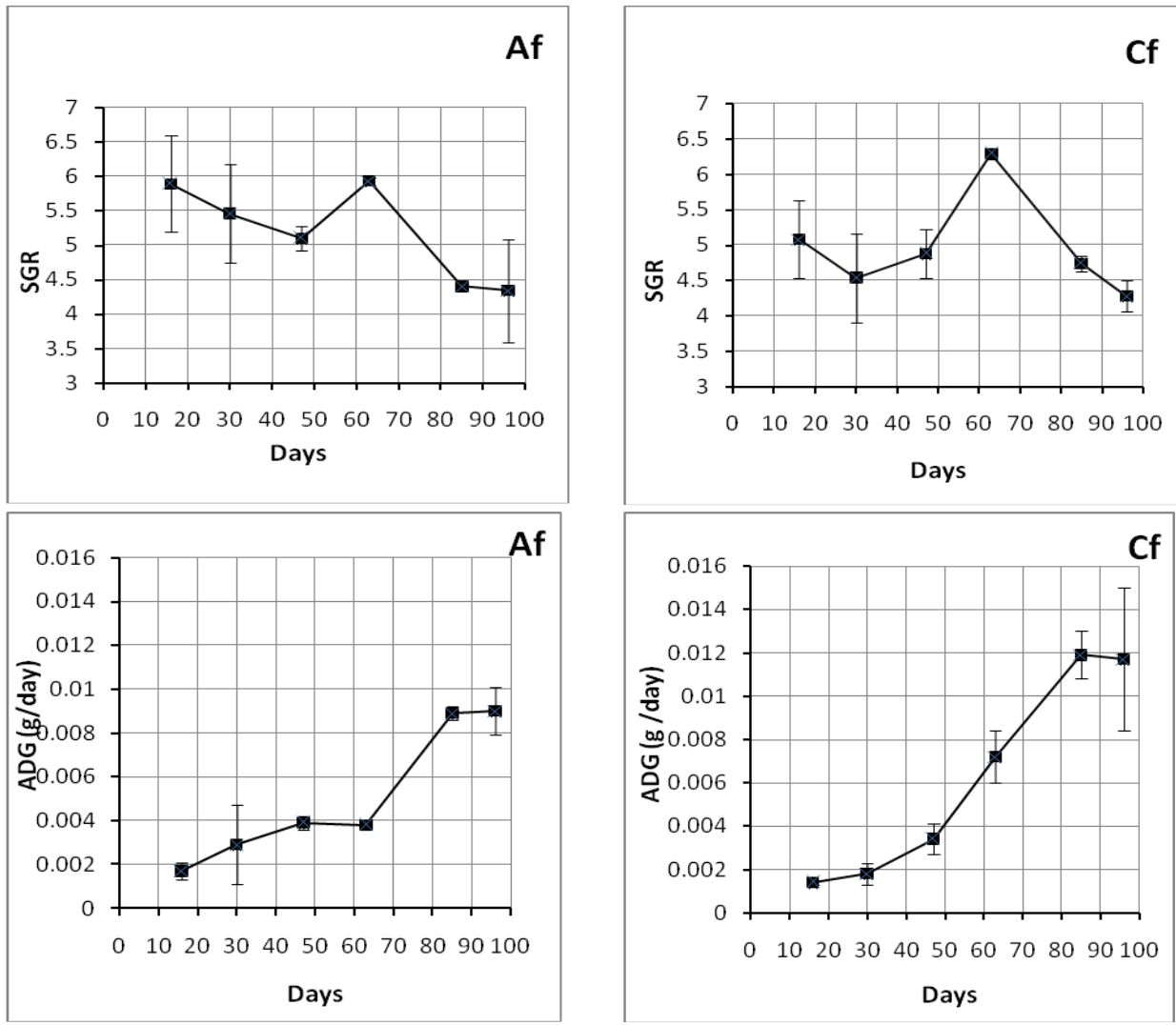

Figure 1. Specific Growth Rate (SGR) and Average Daily Growth (ADG) of the freshwater prawn $(M$. rosenbergii) that fed on commercial feed $(\mathrm{Cf})$ and fish offal substituted aqua-feed (Af) during the 96 days of rearing period.

The weight gain (WG) of the post-larvae fed with Af has shown higher values than that of these fed with Cf up to day 50. After that the values through commercial feed went up and the values through aqua-feed was decreased (Fig.2).

Percentage survival rates of the larvae that fed on Af on days 16, 30 and 47 were $(87.7 \pm 2.08,70 \pm 2.0$ and $63.3 \pm 3.51)$ higher than those of the larvae that fed on Cf $(82.3 \pm 2.52,65.3 \pm 5.77$ and 58.7 \pm 1.53$)$. However, these values were not significantly different $(\mathrm{p}>0.05)$. Nevertheless, \% survival rates of the larvae that fed on Af and Cf $(56.67 \pm 1.15$ and $50.3 \pm 1.0)$ on the day 63 were significantly different $(\mathrm{p}<0.05)$. Although, \% survival of the larvae that fed on Cf were higher in day 85 and $96(50.33 \pm 8.39$ and $44.1 \pm 3.61)$ than the larvae that fed on Af $(47.0 \pm 2.65$ and $42.3 \pm 4.04)$ these were not significantly different $(p>0.05)$ (Table 1$)$. 

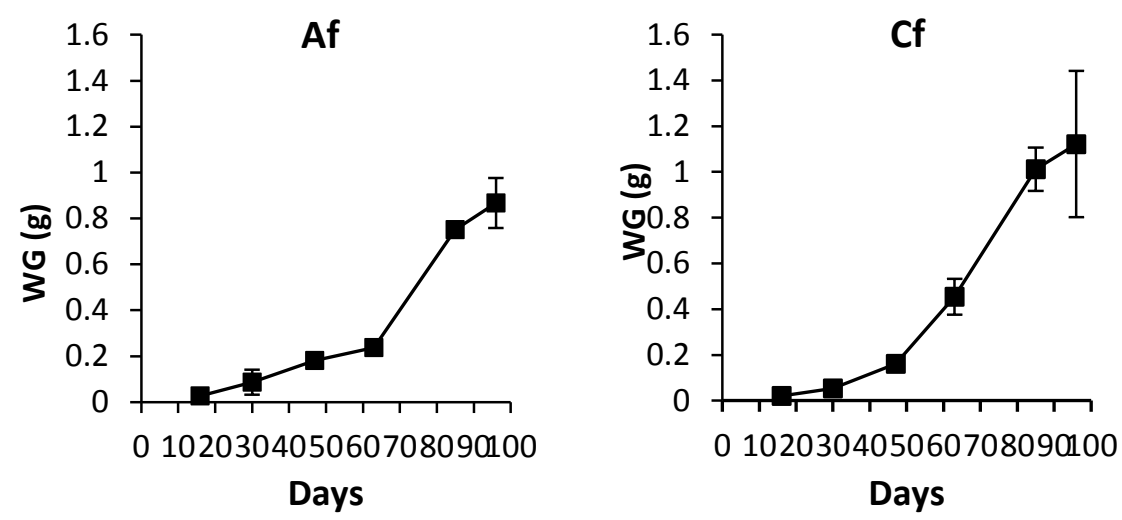

Figure 2. Weight gain (WG) of the freshwater prawn (M. rosenbergii) that fed on commercial feed (Cf) and fish offal substituted aqua-feed (Af) within the 96 days of rearing period.

Table 1. Percentage survival of the freshwater prawn (M. rosenbergii) larvae (PL 20$)$ fed on Commercial feed (Cf) and fish offal substituted aqua-feed (Af) within the 96 days of rearing period.

\begin{tabular}{lllllll}
\hline Feed & \multicolumn{5}{c}{ Mean \% Survival } \\
\cline { 2 - 7 } & Day 16 & Day 30 & Day 47 & Day 63 & Day 85 & Day 96 \\
\hline Cf & $82.3 \pm 2.5^{\mathrm{a}}$ & $65.3 \pm 5.8^{\mathrm{b}}$ & $58.7 \pm 1.5^{\mathrm{c}}$ & $53.1 \pm 1.0^{\mathrm{d}}$ & $50.3 \pm 8.4^{\mathrm{f}}$ & $44.0 \pm 3.6^{\mathrm{g}}$ \\
& & & & & & \\
Af & $87.7 \pm 2.1^{\mathrm{a}}$ & $70.0 \pm 2.0^{\mathrm{b}}$ & $63.4 \pm 3.5^{\mathrm{c}}$ & $56.7 \pm 1.2^{\mathrm{e}}$ & $47.0 \pm 2.6^{\mathrm{f}}$ & $42.3 \pm 4.0^{\mathrm{g}}$ \\
\hline
\end{tabular}

Values in the same column with different superscripts are statistically different $0.05 \%$ level.

The proximate composition of the fish offal substituted aqua-feed (Af) and the commercial prawn feed are shown in Table 2. Commercial prawn feed is nutritionally complete feed for prawn and consist with $36.32 \%$ protein. Nevertheless the aqua-feed consist with $18.63 \%$ protein which is lesser than the $\%$ protein in commercial prawn feed.

Table 2. Proximate compositions of fish offal substituted aqua-feed (Af) and commercial prawn feed (Cf).

\begin{tabular}{lrrrrr}
\hline & \%Moisture & $\begin{array}{r}\text { \%Dry } \\
\text { matter }\end{array}$ & \%Ash & \% Protein & \% Fat \\
\hline $\begin{array}{l}\text { Aqua-feed } \\
\text { (Af) }\end{array}$ & $49.1 \pm 4.6$ & $50.9 \pm 4.5$ & $2.1 \pm 0.8$ & $18.6 \pm 0.8$ & $10-12$ \\
$\begin{array}{l}\text { Commercial } \\
\text { Feed (Cf) }\end{array}$ & $10.3 \pm 0.03$ & $89.7 \pm 0.03$ & $10.5 \pm 0.07$ & $36.3 \pm 0.2$ & $4-6$ \\
\hline
\end{tabular}


Water quality levels observed throughout the experimental period (Table 3) were found to be within the acceptable levels (Boyd 1979).

Table 3. Mean \pm SD values of water quality parameters observed in the tanks where Macrobrachium rosenbergii $\mathrm{PL}_{20}$ fed on commercial feed (Cf) and fish offal substituted aqua-feed (Af) within the 96 days of rearing period. The ranges are given in parentheses.

\begin{tabular}{lll}
\hline Parameter & Af & Cf \\
\hline Temperature $\left({ }^{\circ} \mathrm{C}\right)$ & $28.0 \pm 0.1(26-29.5)$ & $28.1 \pm 0.2(26-29)$ \\
pH & $8.5 \pm 0.1(8.0-9.2)$ & $8.4 \pm 0.0(8.1-8.9)$ \\
Dissolved oxygen $\left(\mathrm{mg} \mathrm{L}^{-1}\right)$ & $9.4 \pm 0.02(8.1-10.5)$ & $9.5 \pm 0.3(8.3-10.5)$ \\
\hline
\end{tabular}

\section{Discussion}

Results indicate that further rearing of $\mathrm{PL}_{20}$ could be done using fish offal-based aquafeed. Based on SGR and ADG, the proposed length of the rearing period is less than 47 days and 47-50 would be the most suitable. Accordingly, this information has to be disseminated to farming communities involved in freshwater prawn culture. This information can also be used to increase the survival and production of the freshwater prawn reared in minor perennial reservoirs. Further, these developments can be used to enhance the profitability of $M$. rosenbergii culture in ponds and minor perennial reservoirs and will generate self-employment for rural communities.

Freshwater prawn larvae are opportunistic feeders (Jiménez-Yan et al. 2006). They can digest and absorb most of the nutrients contained in the feed. In this trial, freshwater prawn larvae have shown comparatively higher growth when fed with Af than $\mathrm{Cf}$ over the period of 47 days until they become PL67. This proposes that the amount of nutrients is sufficient enough to achieve acceptable growth from $\mathrm{PL}_{20}$ $\mathrm{L}_{67}$. These larvae can then be used for further rearing in grow-out ponds, which will contribute towards better survival and better production rates in aquaculture and culture-based fisheries.

In the preparation of feed for rearing the $\mathrm{PL}_{20}$ of freshwater prawn up to $\mathrm{PL}_{67}$, fish offal can be used as the main protein provider instead of fishmeal. According to Balios (2003), fish offal contains all the essential amino acids (EAA) that require for the growth of juvenile prawns (Table4).

The formulated feed had a high level of carbohydrate which was estimated as $70 \%$. Carbohydrate is an inexpensive and immediate source of energy in fish diets (Erfanullah and Jafri 1998). It serves as a precursor for the various intermediary metabolic functions. As such, in the presence of carbohydrate in fish diets the expensive protein component is not used as energy source for the functions that could cover by carbohydrate. Accordingly, larvae fed with this diet can utilize the available carbohydrate for their energy requirement and can spare protein for their growth. Wilson (1994) has shown the presence of carbohydrate in fish diets has a proteinsparing effect similar to that of lipid. It may be the reason for higher growth of $\mathrm{PL}_{20}$ 
up to $\mathrm{PL}_{67}$ when fed with fish offal based aqua-feed. Mitra et al. (2005) has reported that freshwater prawn can grow well with $15 \%$ protein diet in ponds with natural foods. Accordingly, the prepared Af with $18.6 \%$ protein may be sufficient for $\mathrm{PL}_{20}$ rearing up to $\mathrm{PL}_{67}$ (Table 2).

Table 4. Essential amino acid profile (\% in dry weight basis) of the fish offal (Adopted from Balios 2003) and other protein ingredients that are mainly used in fish feed formulation, i.e., fishmeal (Herring) and oil extracted soybean meal. (Adopted from Kai Li et al. (2009).

\begin{tabular}{lccc}
\hline & \multicolumn{3}{c}{ Protein ingredients } \\
\hline & Fish-offal & $\begin{array}{c}\text { Fishmeal } \\
\text { (Herring) }\end{array}$ & Soybean meal \\
\hline Arginine & 1.92 & 3.87 & 3.15 \\
Isoleucine & 2.22 & 2.95 & 2.05 \\
Histidine & 0.98 & 2.40 & 1.34 \\
Leucine & 3.24 & 4.94 & 3.36 \\
Methionine & 1.11 & 1.98 & 0.38 \\
Phenylalanine & 1.67 & 2.81 & 2.27 \\
Threonine & 1.83 & 2.89 & 1.81 \\
Trytophane & 0.37 & 2.15 & 1.50 \\
Lysine & 2.28 & 6.01 & 2.78 \\
Valine & 2.62 & 3.06 & 1.93 \\
Cysteine & 0.51 & 0.31 & 0.26 \\
Tyrosine & 1.32 & 2.15 & 1.50 \\
\hline
\end{tabular}

The increase of ADG of the PL fed on Af as well as those fed on Cf after day 63 may be due to the molting of PL. Lee and Wickins (1992) have recorded that the external shell (exoskeleton) of crustaceans is capable only of limited expansion and that growth occurs through molting intervals throughout life. The decreased growth of PL that were fed on Af after day $47\left(\mathrm{PL}_{63}\right)$ may be due to inadequate essential amino acids and protein that could be provided through fish offal.

However, Hasanuzzaman et al. (2009) have reported the highest weight of prawn when fed on diet where $80 \%$ fishmeal protein was replaced by extracted Soybean meal (SBM). As SBM is an expensive protein ingredient in Sri Lanka, it could not be used in low-cost feed preparation. The formulated Af had 18.6\% protein which was lower than that of Cf. However, faster growth rate of PL was observed with Af until the day 47. Mitra et al. (2005) has obtained similar results for freshwater prawn grown with $15 \%$ protein in ponds with sufficient natural food. In this trial too, certain amounts of natural food may have been produced in culture ponds. 


\section{Acknowledgements}

The financial support received from Hambantota Integrated Coastal Zone Management Project (HICZMP) is gratefully acknowledged. The support provided by Mr. V.G. Nelson, Project Director (Acting) to collect fish offal and to contact fish vendors in this regard is highly appreciated.

\section{References}

APHA (American Public Health Association) 1985. Standard Methods for the Examination of water and wastewater. American water works Association and water pollution control Federation, 16th edn, Washington D.C.

Balazs, G.H. and E. Ross 1976. Effect of protein sources and level on growth and performance of the captive freshwater prawn, Macrobrachium rosenbergii. Aquaculture 7: 299-313. doi:10.1016/0044-8486(76)90127-7

Balios, J. 2003. Nutritional value of fish by-products, and their utilization as fish silage in the nutrition of poultry. 70-76 pp. In: Lekkas T.D. (ed.) Proceedings of $8^{\text {th }}$ International Conference on Environmental Science and Technology,810 September 2003. Lemnos Island, Greece.

Bligh, E.G. \& W.J. Dyer 1959. Gravimetric estimates of lipids. Canadian Journal of Biochemistry and Physiology 37: 9-11.

Boyd, C.E. 1979. Water Quality in warm water Fish Ponds. Auburn University, Alabama. 359p.

Castell, J.D., J.C. Kean, L.R.D. Abramo \& D.E. Conklin 1989. A standard reference diet for crustacean nutrition. 1. Evaluation of two formulations. Journal of World Aquaculture Society 20 (3): 93-99. doi: 10.1111/j.17497345.1989.tb00560.x

Erfanullah \& A.K. Jafri 1998. Growth response, feed utilization and nutrient retension in Catla catla (Ham) fry fed varying levels of dietary carbohydrate. Asian Fisheries Science 11: 223-230.

Fasakin, E.A., B.A. Falayi \& A.A. Eyo 2001. Inclusion of poultry manure in the diet for Nile Tilapia (Oreochromis niloticus, Linneaus). Journal of Fish Technology 2: 51-56.

Hasanuzzaman, A.F., Md. Noman Siddiqui \& Md. Ayaz Hasan Chisty 2009. Optimal replacement of fishmeal with soybean meal in diet for Macrobrachium rosenbergii (De Man 1879) cultured in low saline water. Journal of Fisheries and Aquatic Sciences 9: 17-22.

Hettiarachchi, A. \& M. Kularatne 1988. Observations on small scale pond culture of giant freshwater prawn, Macrobrachium rosenbergii (De Man). Journal of Inland Fisheries 4: 25-29.

Kai Li, Yan Wang, Zhou-Xing Zheng, Rui-Li Jiang \& Ning-Xia Xie 2009. Replacing fish meal with rendered animal protein ingredients in diets for Malabar grouper, Epinephelus malabaricus, reared in net pens. Journal of World Aquaculture Society 40(1): 67-75. doi: 10.1111/j.1749-7345.2008.00227.x 
Jiménez-Yan, L., A. Brito, G. Cuzon, G. Gaxiola, T. García, G. Taboada, L.A. Soto \& R. Brito 2006. Energy balance of Litopenaeus vannamei postlarvae fed on animal or vegetable protein based compounded feeds. Aquaculture 260: 337345. doi:10.1016/j.aquaculture.2006.06.005

Lee, O'C. Daniel \& J.F. Wickins 1992. Crustacean Farming. Blackwell Scientific Publications, Oxford. 392 p.

Mitra, G., P.K. Mukhopadhyay \& D.N. Chattopadhyay 2005. Nutrition and Feeding in Freshwater Prawn (Macrobrachium rosenbergii) farming. Aqua Feeds Formulation Beyond 2: 17-19.

Ricker, W.E. 1979. Growth rate and models. 677-743 pp. In: Hoar, W.S., D.J. Randall and J.R. Brett (eds). Fish Physiology, Vol. VIII. Bioenergetics and Growth. Academic Press, New York.

Wilson, R.P. 1994. Utilization of dietary carbohydrate by fish. Aquaculture 124: 6780. 